\title{
Novel trans-platinum complexes of the histone deacetylase inhibitor valproic acid; synthesis, in vitro cytotoxicity and mutagenicity
}

\author{
Darren M. Griffith ${ }^{\text {a, } *}$, Brian Duff ${ }^{b}$, Kyrill Y. Suponitsky ${ }^{c}$, Kevin Kavanagh ${ }^{\text {b,e }}$, Maria P. Morgan ${ }^{\text {d }}$, \\ Denise Egan ${ }^{\mathrm{b}}$, Celine J. Marmion ${ }^{\mathrm{a}}$ \\ a Centre for Synthesis and Chemical Biology, Department of Pharmaceutical and Medicinal Chemistry, Royal College of Surgeons in Ireland, 123 St. Stephens Green, Dublin 2, Ireland \\ ${ }^{b}$ Centre for Pharmaceutical Research and Development, Department of Science, Institute of Technology Tallaght, Dublin, Dublin 24, Ireland \\ c A. N. Nesmeyanov Institute of Organoelement Compounds, Russian Academy of Sciences, 119991 Moscow, Russian Federation \\ d Molecular E' Cellular Therapeutics, Royal College of Surgeons in Ireland (RCSI), 123 St. Stephen's Green, Dublin 2, Ireland \\ e Medical Mycology Unit, Department of Biology, National University of Ireland, Maynooth, Co. Kildare, Ireland
}

\section{A R T I C L E I N F O}

\section{Article history:}

Received 2 November 2010

Received in revised form 2 March 2011

Accepted 4 March 2011

Available online 14 March 2011

\section{Keywords:}

Trans-Pt complexes

Histone deactylase inhibitor

Valproic acid

Cytotoxicity

Mutagenicity

\begin{abstract}
A B S T R A C T
The first examples of Pt complexes of the well known anti-epilepsy drug and histone deacetylase inhibitor, valproic acid (VPA), are reported. Reaction of the Pt(II) am(m)ine precursors trans- $\left[\mathrm{PtCl}_{2}\left(\mathrm{NH}_{3}\right)(\mathrm{py})\right]$ and trans- $\left[\mathrm{PtCl}_{2}(\mathrm{py})_{2}\right]$ with silver nitrate and subsequently sodium valproate gave trans-[Pt( $\left.\left.\mathrm{VPA}_{-1 \mathrm{H}}\right)_{2}\left(\mathrm{NH}_{3}\right)(\mathrm{py})\right]$ and trans-[Pt( $\left.\left(\mathrm{VPA}_{-1 \mathrm{H}}\right)_{2}(\mathrm{py})_{2}\right]$, respectively. The valproato ligands in both complexes are bound to the Pt(II) centres via the carboxylato functionality and in a monodentate manner. The X-ray crystal structure of trans$\left[\mathrm{Pt}\left(\mathrm{VPA}_{-1 \mathrm{H}}\right)_{2}\left(\mathrm{NH}_{3}\right)(\mathrm{py})\right]$ is described. Replacement of the dichlorido ligands in trans- $\left[\mathrm{PtCl}_{2}(\mathrm{py})_{2}\right]$ and trans$\left[\mathrm{PtCl}_{2}\left(\mathrm{NH}_{3}\right)(\mathrm{py})\right]$ by valproato ligands $\left(\mathrm{VPA}_{-1 \mathrm{H}}\right)$ to yield trans-[Pt $\left.\left(\mathrm{VPA}_{-1 \mathrm{H}}\right)_{2}(\mathrm{py})_{2}\right]$ and trans-[Pt $(\mathrm{VPA}-1 \mathrm{H})_{2}$ $\left.\left(\mathrm{NH}_{3}\right)(\mathrm{py})\right]$ respectively, significantly enhanced cytotoxicity against A2780 (parental) and A2780 cisR (cisplatin resistant) ovarian cancer cells. The mutagenicity of trans-[Pt $\left.(\mathrm{VPA}-1 \mathrm{H})_{2}\left(\mathrm{NH}_{3}\right)(\mathrm{py})\right]$ and trans-[Pt $\left(\mathrm{VPA}_{-1 \mathrm{H}}\right)_{2}(\mathrm{py})_{2}$ ] was determined using the Ames test and is also reported.
\end{abstract}

(c) 2011 Elsevier Inc. All rights reserved.

\section{Introduction}

Currently nearly $50 \%$ of all anti-cancer therapies are platinum (Pt)based $[1,2]$. Surprisingly only three Pt-based drugs have been approved for worldwide clinical use, namely cisplatin, carboplatin and oxaliplatin (Fig. 1) while three others; nedaplatin, heptaplatin and lobaplatin, have been approved only in Japan, South Korea and China, respectively[1,3]. The cytotoxicity of Pt drugs is attributed to their ability to bind DNA and thereby induce DNA damage and ultimately apoptosis $[3,4]$. The application and efficacy of Pt drugs is limited by drawbacks though such as (i) intrinsic or acquired resistance and (ii) toxicity $[3,4]$. Therefore, strong incentives exist for the development of innovative strategies that generate novel $\mathrm{Pt}$ compounds which have different modes of action to those of clinically used Pt drugs. It is conceivable that such novel Pt compounds would potentially target a broader spectrum of human cancers, and in particular cancers where resistance has already emerged to Pt drugs.

Farrell and co-workers initiated a resurgence of interest in the development of trans Pt compounds as potential anti-cancer agents $[5,6]$. Although transplatin for example (Fig. 2) is chemotherapeutically inactive, they demonstrated that substitution of the $\mathrm{NH}_{3}$ carrier

\footnotetext{
* Corresponding author. Tel.: +3531 402 2246; fax: +3531402 2168. E-mail address: dgriffith@rcsi.ie (D.M. Griffith).
}

ligands of transplatin by N-donor heterocycles such as pyridine (py) or thiazole activated a trans geometry. These so called "trans-platinum planar amine" (TPA) complexes (Fig. 2) have comparable cytotoxicities to those seen with both their cis-isomers and that of cisplatin, while retaining activity against tumour cell lines resistant to cisplatin [5-8]. Trans platinum compounds possessing alternative carrier ligands to the N-donor heterocycles such as iminoethers, aliphatic amines and aliphatic heterocyclic amines (Fig. 2) were also investigated and shown to exhibit good activity $[9,10]$.

More recently, Farrell and co-workers improved the profile of their TPA complexes by replacing the chlorido leaving groups with carboxylato ligands $[11,12]$. These trans- $\left[\mathrm{Pt}\left(\mathrm{O}_{2} \mathrm{CR}\right)_{2}(\mathrm{~L})\left(\mathrm{L}^{\prime}\right)\right]$ (where $\mathrm{L}$ and $\mathrm{L}^{\prime}$ are $\mathrm{N}$-donor heterocycles or ammine ligands) or Pt compounds with $\mathrm{N}_{2} \mathrm{O}_{2}$ donor sets have similar cytotoxicities to their $\mathrm{N}_{2} \mathrm{Cl}_{2}$ analogues but offer distinct advantages of being more water soluble, stable to hydrolysis and displaying greater accumulation in cisplatinresistant tumour cells [11-14].

We are interested in combining platinum compounds with molecularly targeted anti-cancer drugs, particularly histone deacetylase (HDAC) inhibitors (HDACIs) $[15,16]$. Histones are the main protein component of chromatin, around which DNA coils. HDACs are a class of zinc metalloenzymes that deacetylate core histone lysine residues, which results in a condensed chromatin structure and ultimately transcriptional repression [17]. Inhibition of HDAC function therefore dramatically affects chromatin structure and thus function. 
<smiles>N[PH](N)(Cl)OC(=O)C1(C(=O)O[Pb](N)(N)OC(=O)OCc2ccccc2)CCC1</smiles>

Cisplatin
Carboplatin

Oxaliplatin

Fig. 1. Structures of cisplatin, carboplatin and oxaliplatin.

More recently HDACIs have been shown to target non histone proteins such as proteins involved in cellular proliferation, migration, death, DNA repair, angiogenesis, inflammation and the immune response [18]. A range of structurally diverse HDACIs have been shown to be effective anti-cancer agents via multiple mechanisms, including inducing cell-cycle arrest, intrinsic and extrinsic apoptotic mechanisms, mitotic cell death, autophagic cell death, generation of reactive oxygen species, inhibiting angiogenesis, and improving NK cell-mediated tumour immunity $[17,18]$. Several of these inhibitors are now undergoing clinical trials [19]. Suberoylanilide hydroxamic acid (SAHA, vorinostat), (Fig. 3) was the first FDA-approved panHDACI to enter the clinic as a treatment for cutaneous T-cell lymphoma [20]. SAHA is also well tolerated in patients, particularly at doses which exhibit a potent anti-cancer effect [21,22].

We recently devised a strategy to derivatise SAHA in such a way so as to facilitate its binding to Pt, while not compromising its HDAC inhibitory activity. In doing so we developed a novel anti-cancer bifunctional Pt drug candidate with dual DNA binding and HDAC inhibitory activity, cis-[Pt $\left(\mathrm{NH}_{3}\right)_{2}$ ( malSAHA $\left.\left._{-2 \mathrm{H}}\right)\right]$ (Fig. 3) [15].

Valproic acid (VPA, 2-propylpentanoic acid), (Fig. 3), a clinically used drug for the treatment of epilepsy, has also been shown to possess HDAC inhibitory activity, along with anti-metastatic and anticancer activities [23]. Consequently, it is currently undergoing clinical trials as an anti-cancer agent either as a single agent, or as part of different combination regimens [24]. In addition, VPA has been shown to exhibit synergistic activity with cisplatin [25] and resensitise cells that have acquired resistance to cisplatin [26].

Given our interest in Pt complexes [15,27-30] and HDAC inhibitors $[15,16,31]$, and the emergence of the TPA complexes with the $\mathrm{N}_{2} \mathrm{O}_{2}$ donor set [8], we sought to develop novel TPA complexes of VPA. We speculated that VPA would enhance the activity of TPA complexes as anti-cancer agents and in doing so target a broader spectrum of human cancers than clinically used Pt drugs. We envisaged that our TPA valproato complexes would hydrolyse in much the same way as carboplatin $[32,33]$ in cells but releasing valproato ligands free to inhibit HDACs and the resulting cytotoxic TPA moiety free to bind DNA nucleobases. Herein we describe the synthesis, characterisation,<smiles>O=C(CCCCCCC(=O)Nc1ccccc1)NO</smiles><smiles>CCCC(CCC)C(=O)O</smiles>

SAHA VPA

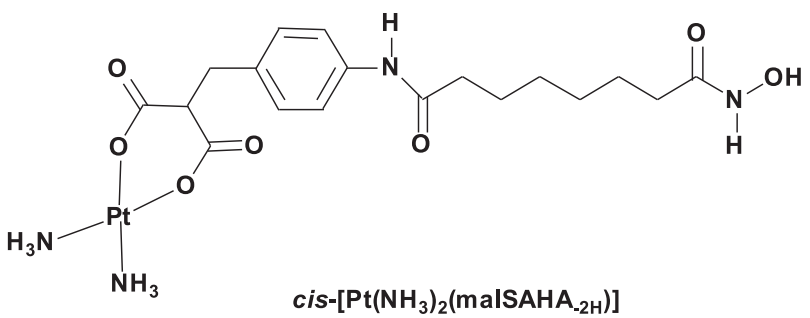

Fig. 3. Structures of SAHA and VPA (HDAC inhibitors) and cis-[Pt( $\left.\mathrm{NH}_{3}\right)_{2}\left(\right.$ malSAHA$\left.\left._{-2 \mathrm{H}}\right)\right]$.

in vitro cytotoxic activity against cisplatin sensitive and resistant ovarian cancer cell lines (A2780 and A2780 cisR) and mutagenicity of novel TPA valproato complexes.

\section{Experimental}

\subsection{Materials and instrumentation}

Sodium valproate, metal salts, solvents and deuterated solvents were all purchased from Sigma Aldrich and used without further purification. Trans- $\left[\mathrm{PtCl}_{2}\left(\mathrm{NH}_{3}\right)\right.$ (py)] and trans- $\left[\mathrm{PtCl}_{2}(\mathrm{py})_{2}\right]$ (where py is pyridine) were prepared by the methods of Ma [11] and Kaufman [34], respectively. IR spectra were recorded as $\mathrm{KBr} \operatorname{discs}\left(4000-400 \mathrm{~cm}^{-1}\right)$ on a Mattson Genesis II CSI FTIR spectrometer and the spectra analysed using WinFirst software. ${ }^{1} \mathrm{H}$ NMR spectra were recorded on a Bruker Avance 400 NMR spectrometer and the spectra analysed using TopSpin 1 software. The residual undeuterated DMSO signal at $2.505 \mathrm{ppm}$ was used as an internal reference. Liquid chromatography-mass spectrometry experiments were performed on a Quattro Micro quadrupole electrospray mass spectrometer (Micromass, Waters Corp., USA): $10 \mu \mathrm{L}$ of the samples were injected in $300 \mu \mathrm{L}$ of acetonitrile:water $(60: 40, \mathrm{v} / \mathrm{v})$. The mass spectrometry data were acquired both in positive and negative ion modes. Elemental analysis ( $\mathrm{C}, \mathrm{H}$, and $\mathrm{N}$ ) were performed by the RCSI Analytical Service, Department of Pharmaceutical and Medicinal Chemistry, Royal College of Surgeons in Ireland, 123 St. Stephens Green, Dublin 2, Ireland.

$$
\stackrel{\mathrm{Cl}}{\mathrm{H}_{3} \mathrm{~N}}-\mathrm{Pt}>\mathrm{NH}_{3}
$$<smiles></smiles><smiles></smiles>

Transplatin<smiles>COC(C)=N[PH](Cl)(Cl)N=C(C)OC</smiles><smiles>CC(C)N[PH](Cl)(Cl)N1CCNCC1</smiles><smiles>CC(=O)O[PH](N)(OC(C)=O)N1CCSC1</smiles>

trans- $\left[\mathrm{PtCl}_{2}\{E-\mathrm{HN}=\mathrm{C}(\mathrm{OMe}) \mathrm{Me}\}_{2}\right]$ 


\subsection{Syntheses}

\subsection{1. trans-[Pt $\left.\left(\mathrm{VPA}_{-1 \mathrm{H}}\right)_{2}\left(\mathrm{NH}_{3}\right)(\mathrm{py})\right]$}

trans-[ $\left.\mathrm{PtCl}_{2}\left(\mathrm{NH}_{3}\right)(\mathrm{py})\right](0.18 \mathrm{~g}, 0.49 \mathrm{mmol})$ and $\mathrm{AgNO}_{3}(0.16 \mathrm{~g}$, $0.95 \mathrm{mmol})$ in deionised water $(6 \mathrm{~mL})$ were stirred overnight in the dark. The insoluble $\mathrm{AgCl}$ was filtered off and sodium valproate $(0.18 \mathrm{~g}$, $1.08 \mathrm{mmol}$ ) was added to the filtrate and the reaction stirred at room temperature for $24 \mathrm{~h}$. An off white solid was filtered and dried over $\mathrm{P}_{2} \mathrm{O}_{5}$. (0.125 g, 44\%). (Found C, 43.7; $\mathrm{H}, 6.7 ; \mathrm{N}, 4.7 \% . \mathrm{C}_{21} \mathrm{H}_{38} \mathrm{~N}_{2} \mathrm{O}_{4}$ Pt requires $\mathrm{C}$, 43.7; H, 6.3; N, 4.9\%); ${ }^{1} \mathrm{H}$ NMR $\delta_{\mathrm{H}}\left(400 \mathrm{MHz}, \mathrm{d}^{6}\right.$ DMSO, $\mathrm{d}=$ doublet, $\mathrm{t}=$ triplet, $\mathrm{s}=$ singlet, $\mathrm{br}=$ broad, $\mathrm{m}=$ multiplet $): 8.52\left(\mathrm{~d}, 2 \mathrm{H},{ }^{3} \mathrm{~J} 5.2 \mathrm{~Hz}\right.$, aromatic $\mathrm{H}), 8.03\left(\mathrm{t}, 1 \mathrm{H},{ }^{3} \mathrm{~J} 7.6 \mathrm{~Hz}\right.$, aromatic $\left.\mathrm{H}\right), 7.54\left(\mathrm{t}, 2 \mathrm{H},{ }^{3} \mathrm{~J} 7.0 \mathrm{~Hz}\right.$, aromatic $\mathrm{H}), 4.73\left(\mathrm{~s}, 3 \mathrm{H}, \mathrm{br}, \mathrm{NH}_{3}\right), 2.08(\mathrm{~m}, 2 \mathrm{H}, \mathrm{CH}), 1.33\left(\mathrm{~m}, 4 \mathrm{H}, \mathrm{CH}_{2}\right)$, $1.11\left(\mathrm{~m}, 12 \mathrm{H}, \mathrm{CH}_{2}\right), 0.79\left(\mathrm{t}, 12 \mathrm{H}, \mathrm{CH}_{3}\right) ;{ }^{13} \mathrm{C}$ NMR $\delta_{\mathrm{C}}\left(100 \mathrm{MHz}, \mathrm{d}^{6} \mathrm{DMSO}\right)$ : 182.1 (C O), 151.60 (aromatic C), 138.62 (aromatic C), 125.33 (aromatic C), 46.52 ( $\mathrm{CH}$ valproato), 35.11 ( $\mathrm{CH}_{2}$ valproato), 20.21 ( $\mathrm{CH}_{2}$ valproato), $14.00\left(\mathrm{CH}_{3}\right.$ valproato); IR $\nu_{\max }\left(\mathrm{cm}^{-1}, \mathrm{br}=\right.$ broad, $\mathrm{s}=$ strong, vs $=$ very strong) 3256 br, 3179 br, 2955 s, 2932 s, 2872 s, 1628 s, 1615 vs, 1609 vs, 1453 vs, 1383 vs. ESI-MS m/z: 578.19 (calcd. 578.24) ([M-H] $\left.]^{+}\right)$.

\subsection{2. trans- $\left[\mathrm{Pt}(\mathrm{VPA}-1 \mathrm{H})_{2}(\mathrm{py})_{2}\right]$}

trans- $\left[\mathrm{PtCl}_{2}(\mathrm{py})_{2}\right](0.25 \mathrm{~g}, 0.59 \mathrm{mmol})$ and $\mathrm{AgNO}_{3}(0.19 \mathrm{~g}, 1.17 \mathrm{mmol})$ in a mixture of deionised water $(6 \mathrm{~mL})$ and DMF $(4 \mathrm{~mL})$ were stirred at $60{ }^{\circ} \mathrm{C}$ in the dark for $24 \mathrm{~h}$. The insoluble $\mathrm{AgCl}$ was filtered off and sodium valproate $(0.22 \mathrm{~g}, 1.29 \mathrm{mmol})$ was added to the filtrate and the reaction stirred at room temperature for $24 \mathrm{~h}$. An off white solid was filtered and dried over $\mathrm{P}_{2} \mathrm{O}_{5}(0.06 \mathrm{~g}, 16 \%$ ). (Found $\mathrm{C}, 48.5 ; \mathrm{H}, 6.2 ; \mathrm{N}, 4.3 \%$. $\mathrm{C}_{26} \mathrm{H}_{40} \mathrm{~N}_{2} \mathrm{O}_{4}$ Pt requires $\left.\mathrm{C}, 48.8 ; \mathrm{H}, 6.3 ; \mathrm{N}, 4.4 \%\right) ;{ }^{1} \mathrm{H}$ NMR $\delta_{\mathrm{H}}(400 \mathrm{MHz}$, $\mathrm{d}^{6}$ DMSO): 8.66 (dd, $4 \mathrm{H},{ }^{3} \mathrm{~J} 4.8 \mathrm{~Hz},{ }^{4} \mathrm{~J} 1.6 \mathrm{~Hz}$, aromatic $\left.\mathrm{H}\right), 8.00(\mathrm{~m}, 2 \mathrm{H}$, aromatic $\mathrm{H}), 7.53(\mathrm{~m}, 4 \mathrm{H}$, aromatic $\mathrm{H}), 2.03(\mathrm{~m}, 2 \mathrm{H}, \mathrm{CH}), 1.22\left(\mathrm{~m}, 4 \mathrm{H}, \mathrm{CH}_{2}\right)$, $1.05\left(\mathrm{~m}, 4 \mathrm{H}, \mathrm{CH}_{2}\right), 0.78\left(\mathrm{~m}, 8 \mathrm{H}, \mathrm{CH}_{2}\right), 0.64\left(\mathrm{t}, 12 \mathrm{H}, \mathrm{CH}_{3}\right) ;{ }^{13} \mathrm{C} \mathrm{NMR} \delta_{\mathrm{C}}$ (100 MHz, d ${ }^{6}$ DMSO): 183.90 (C O), 150.98 (aromatic C), 137.66 (aromatic C), 123.73 (aromatic C), 45.41 ( $\mathrm{CH}$ valproato), $34.29\left(\mathrm{CH}_{2}\right.$ valproato), 18.99 ( $\mathrm{CH}_{2}$ valproato), $11.57\left(\mathrm{CH}_{3}\right.$ valproato); $\operatorname{IR} \nu_{\max }\left(\mathrm{cm}^{-1}\right)$, 2954 s, 2931 s, 2871 s, 1629 vs, 1602 vs, 1452 vs, 1380 vs. ESI-MS m/z:

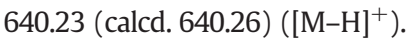

\subsection{Crystallographic measurements on trans-[Pt $\left.\left(\mathrm{VPA}_{-1 \mathrm{H}}\right)_{2}\left(\mathrm{NH}_{3}\right)(\mathrm{py})\right]$}

Single crystals of trans-[Pt( $\left.\left.\mathrm{VPA}_{-1 \mathrm{H}}\right)_{2}\left(\mathrm{NH}_{3}\right)(\mathrm{py})\right]$ suitable for an X-ray study were obtained by slow evaporation from the mother liquor and as thin plates with relatively weak reflection ability. Crystal data (Table 1) was collected on SMART APEX2 CCD diffractometer at $100 \mathrm{~K}$ using monochromated Mo- $K_{\alpha}$ radiation, $(\lambda=0.71073 \AA)$. An analysis of the measured intensities was carried out with the SAINT and SADABS programmes included in the APEX2 programme package [35], taking into account an absorption correction by the semi-empirical method. The structures were solved by the direct methods and refined by the fullmatrix least-squares procedure against $F^{2}$ in anisotropic approximation. Ammonium hydrogen atoms were located in the difference Fourier maps and were then shifted at the standard $\mathrm{X}$-ray values for $\mathrm{N}-\mathrm{H}$ bonds $(0.9 \AA)$ and included in the refinement using riding approximation $\left(U_{i s o}\right.$ $\left.(\mathrm{H})=1.2 U_{e q}(\mathrm{~N})\right)$. All the other hydrogen atoms were placed in geometrically calculated positions and refined within riding model $\left(U_{i s o}(\mathrm{H})=n U_{e q}(\mathrm{C})\right.$, where $n=1.5$ for methyl hydrogen atoms and $n=1.2$ for all the other hydrogens). The refinement was carried out with the SHELXTL programme [36].

\subsection{Mutagenicity}

The possible genotoxicity of test agents was investigated using the Standard Ames bacterial mutation assay described by Maron and Ames [37]. The primary tester strains used were Salmonella typhimurium strains TA98 and TA100 (Trinova, Germany), which detect mutation by frame-shift and base-pair substitution, respectively. Both strains carry the ampicillin resistance plasmid pKM101. Tester strains were cultured
Table 1

Crystallographic data for trans-[Pt( $\left.\left.\mathrm{VPA}_{-1 \mathrm{H}}\right)_{2}\left(\mathrm{NH}_{3}\right)(\mathrm{py})\right]$.

\begin{tabular}{ll}
\hline Compound & \\
\hline Empirical formula & $\mathrm{C} 21 \mathrm{H} 38 \mathrm{~N} 2 \mathrm{O} 4 \mathrm{Pt}$ \\
Formula weight & 577.62 \\
Temperature & $100(2) \mathrm{K}$ \\
Wavelength & $0.71073 \AA$ \\
Crystal system & Monoclinic \\
Space group & $\mathrm{P} 2 / \mathrm{c}$ \\
a, $\AA$ & $9.8826(11)$ \\
$\mathrm{b}, \AA$ & $10.8078(12)$ \\
c, $\AA$ & $22.035(2)$ \\
$\beta,{ }^{\circ}$ & $95.043(2)$ \\
Volume, $\AA^{3}$ & $2344.4(4)$ \\
$\mathrm{Z}$ & 4 \\
Density (calculated) & $1.636 \mathrm{~g} / \mathrm{cm}^{3}$ \\
Absorption coefficient & $6.012 \mathrm{~mm}{ }^{-1}$ \\
F(000) & 1152 \\
Crystal size, mm & $0.12 \times 0.10 \times 0.01$ \\
Theta range for data collection & 1.86 to 27.99 \\
Reflections collected & 42088 \\
Independent reflections (R(int) & $5617(0.0820)$ \\
Completeness to theta $=27.99$ & $99.2 \%$ \\
Absorption correction & Semi-empirical from equivalents \\
Max. and min. transmissions & 0.942 and 0.463 \\
Data/restraints/parameters & $5617 / 0 / 261$ \\
Goodness-of-fit on F ${ }^{2}$ & 0.994 \\
Final R indices [for 4062 rfln with I $>2$ sigma(I)] & $\mathrm{R} 1=0.0342$, wR2 $=0.0721$ \\
R indices (all data) & $\mathrm{R} 1=0.0597, \mathrm{wR} 2=0.0828$ \\
Largest diff. peak and hole, e. $\AA^{-3}$ & 1.859 and -1.426 \\
\hline &
\end{tabular}

in Oxoid nutrient broth No. 2 to a cell density of $1 \times 10^{9}$ cells $/ \mathrm{mL}$ (OD of 0.60 at $605 \mathrm{~nm}$ ) and maintained on master plates for routine inoculation. Both tester strains were then grown on minimal glucose plates, supplemented with $0.5 \mathrm{mM}$ histidine/biotin and ampicillin.

To carry out the Ames test, top agar $[0.3 \%(\mathrm{w} / \mathrm{v})$ agar and $0.5 \%(\mathrm{w} / \mathrm{v})$ $\mathrm{NaCl}$ ] was supplemented with $10 \mathrm{~mL}$ of $0.5 \mathrm{mM}$ histidine/biotin per $100 \mathrm{~mL}$ of agar, immediately prior to use. A $2 \mathrm{~mL}$ aliquot of top agar was distributed into a sterile universal. A mammalian enzyme activation system was also included, which consisted of the S9 liver fraction of a male Sprague-Dawley rat, induced with aroclor 1254. A $500 \mu$ liquot of S9 mixture $(10 \%, \mathrm{v} / \mathrm{v}), 100 \mu \mathrm{l}$ of test agent at the appropriate concentration dissolved in $0.1 \mathrm{M} \mathrm{PBS}, \mathrm{pH} 7.4$, and $100 \mu \mathrm{l}$ of tester strains were added to $2 \mathrm{~mL}$ aliquots of molten top agar, mixed and quickly poured over the surface of minimal glucose plates lacking histidine/ biotin. All plates were then protected from light, allowed to solidify, inverted and then incubated at $37^{\circ} \mathrm{C}$ for $72 \mathrm{~h}$. Following incubation, the number of revertant colonies was determined per plate. Each test concentration was analysed in triplicate, in both the presence and absence of the S9 enzyme activation system. Negative control plates used consisted of tester strain and S9 mix alone, while the solventtreated control consisted of tester strain, S9 mixture and solvent vehicle (no test agent). This approach allowed identification and quantification of spontaneous bacterial revertants. Positive controls included the known mutagens, 4-nitroquinoline- $N$-oxide (NQNO) for TA98 (1$1000 \mathrm{ng} /$ plate) and sodium azide $(0.5-10 \mu \mathrm{g} /$ plate) for TA100. The metabolising activity of the rat liver S9 was tested in both strains using 2-aminoanthracene, as this mutagen required metabolic activation in order to induce mutations.

\subsection{In vitro cytotoxicity}

The in vitro anti-cancer chemotherapeutic potential of our test agents was determined using two human-derived malignant ovarian model cell lines; A2780 and A2780 cisR. Both cell lines were purchased from the European Collection of Cell Cultures and maintained in RPMI1640 media with Earle's balanced salt solution (EBSS) containing $1.5 \mathrm{~g} / \mathrm{L}$ sodium bicarbonate, $2 \mathrm{mM} \mathrm{L-glutamine,} 100 \mathrm{U} / \mathrm{mL}$ penicillin, $100 \mu \mathrm{g} / \mathrm{mL}$ streptomycin, along with $10 \%(\mathrm{v} / \mathrm{v}$ ) foetal bovine serum (FBS). All cell 

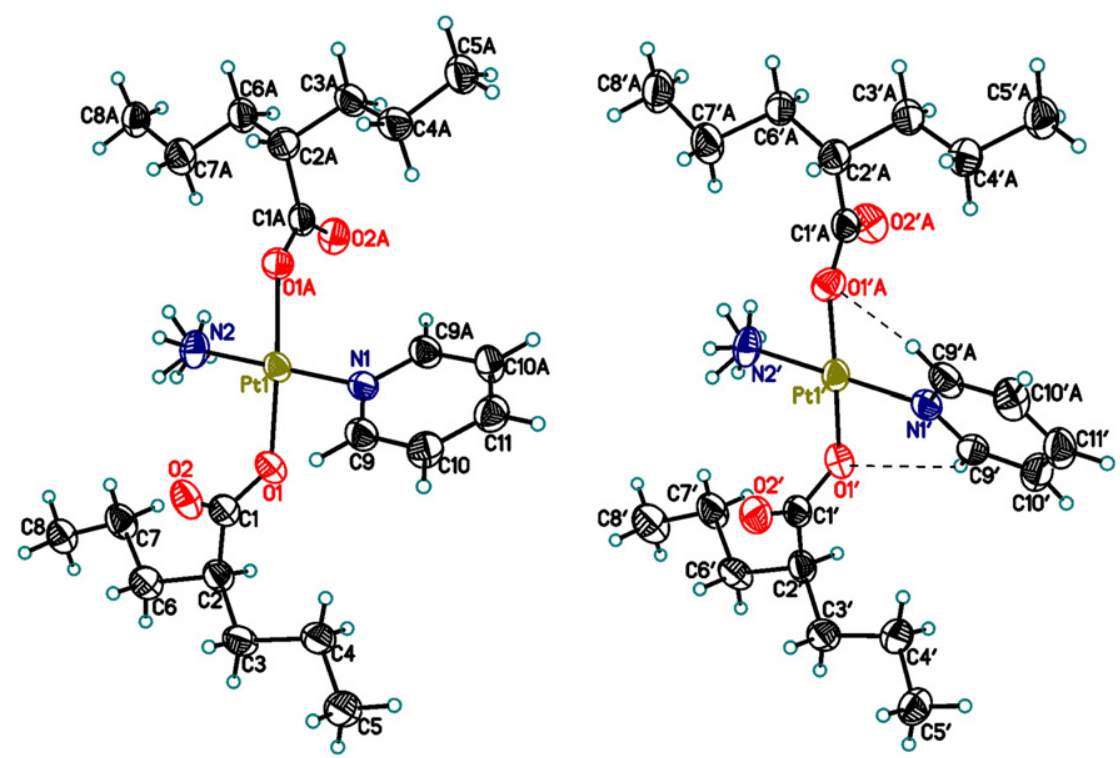

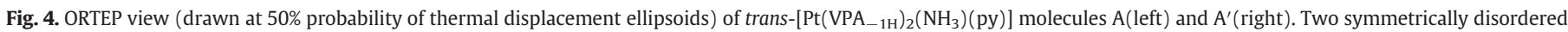
components of $\mathrm{NH}_{3}$ group shown by solid and open lines, correspondingly. Atoms labelled with letters A are generated by a two-fold symmetry axis.

culture reagents were purchased from Sigma-Aldrich Ireland, Ltd, unless otherwise stated.

The cisplatin-resistant human ovarian cell line, namely A780 cisR, was previously developed by chronic exposure of the parent cisplatin sensitive A2780 cell line to increasing concentrations of cisplatin. A2780 cisR cells are known to be cross-resistant to melphalan, adriamycin and irradiation. Resistance was maintained by, every third passage, culturing these cells in $1 \mu \mathrm{M}$ cisplatin, and cells were maintained as above. Both model cell lines were incubated at $37{ }^{\circ} \mathrm{C}$ in a humidified atmosphere, containing $95 \%$ air with $5 \% \mathrm{CO}_{2}$.

Each of the two cell lines $(100 \mu \mathrm{l})$ were seeded at a density of $5 \times 10^{4}$ cells $/ \mathrm{mL}$ into sterile 96 wells of flat-bottomed plates and grown in 5\% $\mathrm{CO}_{2}$ at $37^{\circ} \mathrm{C}$. Test compounds were dissolved in dimethylformamide (DMF) and diluted with complete culture media. The maximum percentage of DMF present in all wells was $0.5 \%(\mathrm{v} / \mathrm{v})$. Each drug solution $(100 \mu \mathrm{l})$ was added to replicate wells in the concentration range of $1-100 \mu \mathrm{M}$, and incubated for $72 \mathrm{~h}$. A miniaturised viability assay using 3-(4,5-dimethylthiazol-2-yl)-2,5-diphenyl tetrazolium bromide (MTT) was carried out according to the method described previously [38]. The $\mathrm{IC}_{50}$ value for each drug was calculated and this is defined as the drug concentration causing a $50 \%$ reduction in cellular viability. Each assay was carried out using five replicates and repeated on three separate occasions. Viability was calculated as a percentage of solventtreated control cells, and expressed as a \% of control. The significance of any reduction in cellular viability was determined using one-way ANOVA (analysis of variance). A probability of 0.05 or less was deemed statistically significant.

Table 2

Selected bond lengths $(\AA)$ and angles $\left({ }^{\circ}\right)$ for trans-[Pt $\left.\left(\operatorname{VPA}_{-1 \mathrm{H}}\right)_{2}\left(\mathrm{NH}_{3}\right)(\mathrm{py})\right]$

\begin{tabular}{lcc}
\hline Bond, $\AA$ & Molecule A & Molecule A' \\
\hline Pt1-01 & $2.008(4)$ & $2.017(4)$ \\
Pt1-N1 & $1.998(6)$ & $2.017(6)$ \\
Pt1-N2 & $2.026(6)$ & $2.050(6)$ \\
& & \\
Bond angle, $^{\circ}$ & Molecule A & Molecule A' \\
\hline O1-Pt1-N1 & $91.95(10)$ & $90.91(10)$ \\
O1-Pt1-N2 & $88.05(10)$ & $89.09(10)$ \\
O1-Pt1-O1A & $176.1(2)$ & $178.2(2)$ \\
N1-Pt1-N2 & $180.000(2)$ & $180.000(2)$ \\
\hline
\end{tabular}

Atoms denoted with letter A are generated by a two-fold symmetry axis.

\section{Results and discussion}

\subsection{Syntheses of platinum valproic acid complexes}

The TPA precursors, trans-[ $\left.\mathrm{PtCl}_{2}\left(\mathrm{NH}_{3}\right)(\mathrm{py})\right]$ and trans-[ $\left.\mathrm{PtCl} \mathrm{C}_{2}(\mathrm{py})_{2}\right]$ were reacted with silver nitrate to give the corresponding nitrato compounds, which were subsequently reacted with sodium valproate to give trans-[Pt( $\left.\left(\mathrm{VPA}_{-1 \mathrm{H}}\right)_{2}\left(\mathrm{NH}_{3}\right)(\mathrm{py})\right]$ and trans-[Pt( $\left.\left(\mathrm{VPA}_{-1 \mathrm{H}}\right)_{2}(\mathrm{py})_{2}\right]$ respectively.

Both complexes were formed in reasonably poor yields (44\% and $16 \%$ for trans-[Pt( $\left.\left(\mathrm{VPA}_{-1 \mathrm{H}}\right)_{2}(\mathrm{py})_{2}\right]$ and trans-[Pt( $\left.\left(\mathrm{VPA}_{-1 \mathrm{H}}\right)_{2}\left(\mathrm{NH}_{3}\right)(\mathrm{py})\right]$ respectively) and characterised by elemental analysis, infrared and ${ }^{1} \mathrm{H}$ NMR spectroscopy and mass spectrometry. Elemental-analytical data for both complexes are consistent with the presence of diam(m)ine Pt(II) moieties bound to two VPA $-1 \mathrm{H}$ ligands and the absence of counterions suggesting neutral complexes. The presence of two $\mathrm{VPA}_{-1 \mathrm{H}}$ ligands per $\mathrm{Pt}(\mathrm{II})$ centre suggests also that the $\mathrm{VPA}_{-1 \mathrm{H}}$ ligands are coordinated in a monodentate fashion.

IR spectroscopy proved a particularly useful technique for characterisation of the metal carboxylato complexes and assisted in confirming the coordination modes of the $\mathrm{VPA}_{-1 \mathrm{H}}$ ligand. Carboxylic acids may coordinate metals in a monodentate, bidentate or bridging mode and metal carboxylato complexes display asymmetric, $v_{\mathrm{a}}(\mathrm{COO})$, and symmetric, $v_{s}(\mathrm{COO})$, stretching bands [39]. The IR spectra of trans-[Pt $\left.\left(\mathrm{VPA}_{-1 \mathrm{H}}\right)_{2}\left(\mathrm{NH}_{3}\right)(\mathrm{py})\right]$ and trans-[Pt(VPA $\left.\left.-1 \mathrm{H}\right)_{2}(\mathrm{py})_{2}\right]$ display $\nu_{\mathrm{a}}(\mathrm{COO})$ bands at ca. $1630 \mathrm{~cm}^{-1}(\mathrm{KBr})$, showing a shift to lower wavenumbers than in the uncoordinated VPA $\left(1706 \mathrm{~cm}^{-1}\right.$, liquid film) as well as symmetric stretching $v_{s}(\mathrm{COO})$ bands at ca. $1380 \mathrm{~cm}^{-1}(\mathrm{KBr})$. In addition the $\Delta$ values $\left[v_{\mathrm{a}}(\mathrm{COO})-v_{\mathrm{s}}(\mathrm{COO})\right]$ for the Pt complexes (ca. 250) are greater than the $\Delta$ values for the corresponding carboxylate ion (e.g. sodium valproate, $\mathrm{KBr}$, and 144). This observation supports the hypothesis that

Table 3

H-bonding parameters for trans-[Pt( $\left.\left(\mathrm{VPA}_{-1 \mathrm{H}}\right)_{2}\left(\mathrm{NH}_{3}\right)(\mathrm{py})\right]^{*}$.

\begin{tabular}{|c|c|c|c|c|}
\hline D-H...A & $\mathrm{d}(\mathrm{D}-\mathrm{H}), \AA$ & $\mathrm{d}(\mathrm{D} \ldots \mathrm{A}), \AA$ & $\mathrm{d}(\mathrm{H} . . . \mathrm{A}), \AA$ & $<$ DHA, ${ }^{\circ}$ \\
\hline $\mathrm{N} 2-\mathrm{H} 2 \mathrm{~B} . . . \mathrm{O} 2^{\prime} \mathrm{A}$ & 0.90 & 2.812 & 2.051 & 142 \\
\hline N2-H2D...O2' & 0.90 & 2.812 & 2.141 & 131 \\
\hline $\mathrm{N} 2^{\prime}-\mathrm{H} 2 \mathrm{~B}^{\prime} \ldots \mathrm{O} 2$ & 0.90 & 2.895 & 2.104 & 146 \\
\hline $\mathrm{N} 2^{\prime}-\mathrm{H}_{2} \mathrm{D}^{\prime} \ldots \mathrm{O} 2 \mathrm{~B}$ & 0.90 & 2.895 & 2.194 & 134 \\
\hline
\end{tabular}

* Atoms denoted with letters $A$ and $B$ are generated by symmetry codes $-\mathrm{x}, \mathrm{y},-\mathrm{z}+1 / 2$ and $-\mathrm{x}+1, \mathrm{y},-\mathrm{z}+1 / 2$, correspondingly. 
valproato coordination to the $\mathrm{Pt}(\mathrm{II})$ centre is monodentate in both complexes [39].

In the ${ }^{1} \mathrm{H}$ NMR spectrum of trans-[Pt( $\left.\left.\mathrm{VPA}_{-1 \mathrm{H}}\right)_{2}(\mathrm{py})_{2}\right]$ the pyridine proton signals ( $\mathrm{C} 9, \mathrm{C} 11$ and $\mathrm{C} 10$, see Fig. 4, where $\mathrm{NH}_{3}$ is replaced with pyridine for trans-[Pt(VPA $\left.-1 \mathrm{H})_{2}(\mathrm{py})_{2}\right]$ and the two pyridines have identical numbering), are found at $8.66,8.00$ and 7.53 ppm respectively and integrate for 10 protons. The methine ( $\mathrm{C} 2$ ), methylene ( $\mathrm{C} 3$ and $\mathrm{C} 4$ ) and methyl (C5) proton signals of the bound $\mathrm{VPA}_{-1 \mathrm{H}}$ ligands are found at 2.03, $1.22,1.05$ and $0.78 \mathrm{ppm}$ and integrate in total for 30 protons.

In the ${ }^{1} \mathrm{H}$ NMR spectrum of trans-[Pt $\left.\left(\mathrm{VPA}_{-1 \mathrm{H}}\right)_{2}\left(\mathrm{NH}_{3}\right)(\mathrm{py})\right]$ the pyridine proton signals (C9, C11 and C10, Fig. 4) are found at 8.52, 8.03 and $7.54 \mathrm{ppm}$ respectively but integrate for 5 protons in total. In trans$\left[\mathrm{Pt}\left(\mathrm{VPA}_{-1 \mathrm{H}}\right)_{2}\left(\mathrm{NH}_{3}\right)(\mathrm{py})\right]$ the ammine proton signal is found at $4.73 \mathrm{ppm}$ and integrates for three protons. The methine (C2), methylene (C3 and C4) and methyl (C5) proton signals of the bound $\mathrm{VPA}_{-1 \mathrm{H}}$ ligands, Fig. 4, are found at 2.08, 1.33, 1.11 and $0.79 \mathrm{ppm}$ and also integrate in total for 30 protons.

In the ${ }^{13} \mathrm{C}$ NMR spectrum of both symmetrical complexes the carbonyl carbon signal (C1) is found at ca. $183 \mathrm{ppm}$ and the three pyridine carbon signals (C9, C11 and C10) are found at ca. 150, 138 and 125 ppm respectively, Fig. 4. The methine (C2), methylene (C3 and C4) and methyl (C5) carbon signals of the bound VPA $-1 \mathrm{H}$ ligands, Fig. 4, are found at ca. 46, 35, 20 and 13 ppm respectively for both complexes.

ESI-MS in the positive mode was used to assist in identifying the platinum complexes; mass peaks at 640.23 and $578.19 \mathrm{amu}$ were observed for trans-[Pt( $\left.\left(\mathrm{VPA}_{-1 \mathrm{H}}\right)_{2}(\mathrm{py})_{2}\right]$ and trans-[Pt $(\mathrm{VPA}-1 \mathrm{H})_{2}\left(\mathrm{NH}_{3}\right)$ (py)] respectively. All of the spectra display the correct isotopic patterns.

An X-ray crystal structure was solved for trans-[Pt( $\mathrm{VPA}-1 \mathrm{H})_{2}\left(\mathrm{NH}_{3}\right)$ (py)].

\subsection{Crystal structure of trans-[Pt $\left.\left(V P A_{-1 H}\right)_{2}\left(N_{3}\right)(p y)\right]$}

The atomic numbering scheme and atom connectivity for trans-[Pt $\left.\left(\mathrm{VPA}_{-1 \mathrm{H}}\right)_{2}\left(\mathrm{NH}_{3}\right)(\mathrm{py})\right]$ is shown in Fig. 4 and a selection of bond lengths and angles are reported in Table 2.

An asymmetric unit cell of trans-[Pt $\left.\left(\mathrm{VPA}_{-1 \mathrm{H}}\right)_{2}\left(\mathrm{NH}_{3}\right)(\mathrm{py})\right]$ contains two halves of Pt-complexes ( $\mathrm{A}$ and $\mathrm{A}^{\prime}$ ) which are both located on the two-fold symmetry axes. The ammine protons are disordered over two symmetrical positions with equal occupancies. A general view of these molecules is shown in Fig. 4. In both complexes, the platinum atom adopts square planar geometry. All the N-Pt-N, N-Pt-O and $\mathrm{O}-\mathrm{Pt}-\mathrm{O}$ angles are nearly $90^{\circ}$ and $180^{\circ}$, correspondingly (see Table 1 ). The valproic carboxylato groups in both molecules are nearly perpendicular to the alkyl chains of the valproato ligands. The disparity between the two independent Pt complexes is in the orientation of the pyridine ligand. There is a difference in rotation about $\mathrm{Pt} 1-\mathrm{N} 1$ ( $\left.\mathrm{Pt} 1^{\prime}-\mathrm{N} 1^{\prime}\right)$ bond; in molecule $A$ the torsion angle for 01-Pt1-N1-C9 is $-59.4(3)^{\circ}$ where as in molecule $\mathrm{A}^{\prime}$ it is $-23.0(3)^{\circ}$. This results in a slightly shortened $\mathrm{C9}^{\prime}-\mathrm{H}^{\prime}$ A...O1' contact ( $\mathrm{C} . . . \mathrm{O}$ is 2.960 (7) $\AA$, $\mathrm{H}$...O is $2.42 \AA$, $<\mathrm{CHO}$ is $116^{\circ}$ ) in $\mathrm{A}^{\prime}$. In molecule $\mathrm{A}$, this distance corresponds to a normal nonbonded contact (H9....01 is $3.02 \AA$, no H-bond is formed). Therefore the orientation of the pyridine ring is predominantly defined by the effect of the crystal packing rather than by the intramolecular $\mathrm{C}-\mathrm{H}$...O interaction.

In the crystal, the Pt molecules are connected to each other by a $\mathrm{H}$-bond network. The ammine protons are $\mathrm{H}$-bonded to the carboxylato $\mathrm{O} 2\left(\mathrm{O}^{\prime}\right)$ atoms (Table 3$)$. This leads to the formation of $\mathrm{H}$-bond chains in the direction of the $a$ axis. Each chain is built up of alternate $A$ and $A^{\prime}$ molecules. In the $a b$ plane, these chains are interpenetrated by pyridine moieties. Two adjacent pyridine rings from different chains are nearly perpendicular to each other; the closest intermolecular distance is

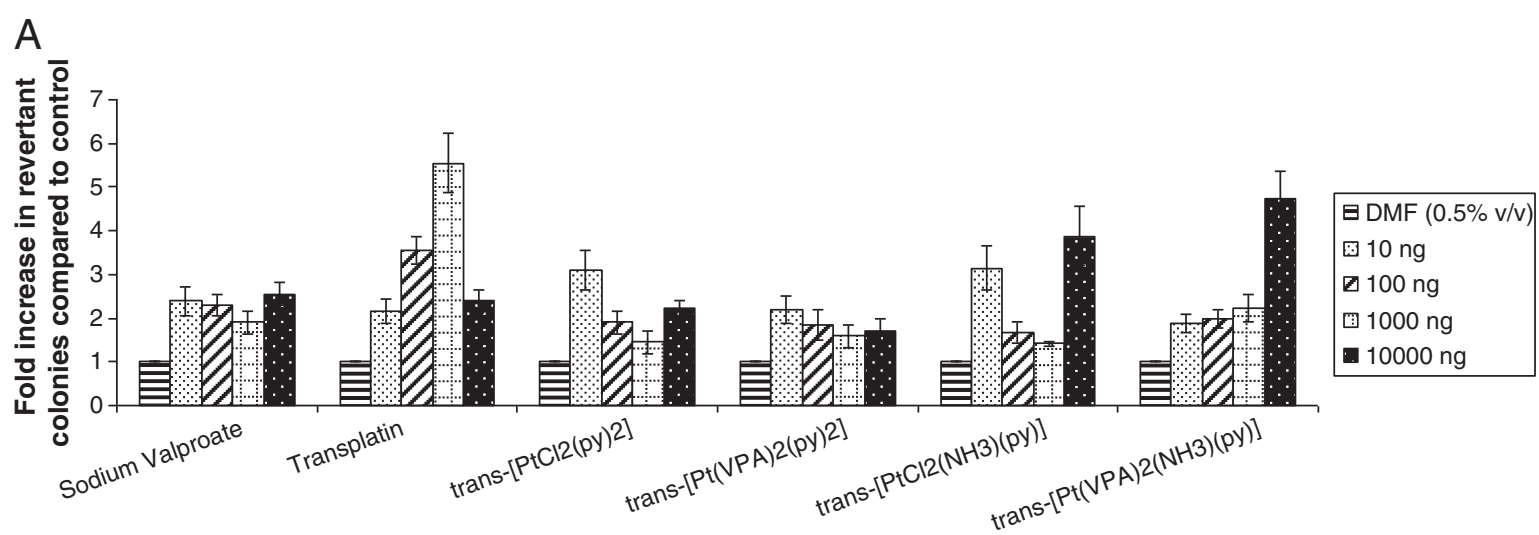

B

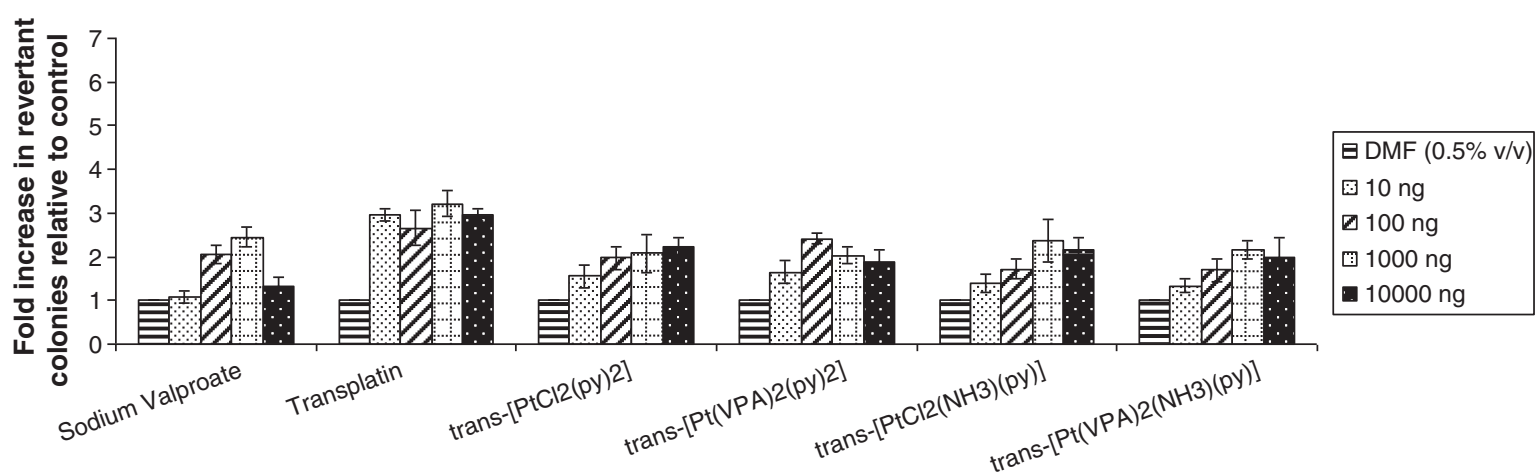

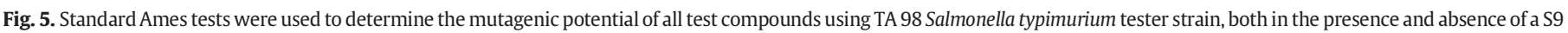

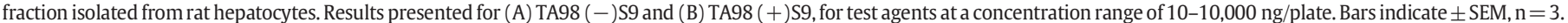


observed between $\mathrm{C} 11^{\prime} \ldots \mathrm{H} 9 \mathrm{~A}$ atoms and is equal to $3.00 \AA$. This does not imply any strong interchain interactions but such packing is responsible for the different orientation of the pyridine rings in $\mathrm{A}$ and $\mathrm{A}^{\prime}$.

\subsection{Mutagenicity}

The mutagenicity of our test agents was determined using the Ames test and the data is presented in Figs. 5 and 6. For a compound to be considered as a possible mutagen, a fold-related increase in revertant colonies must be observed with increasing concentration. Data presented shows that trans-[Pt( $\left.\left(\mathrm{VA}_{-1 \mathrm{H}}\right)_{2}\left(\mathrm{NH}_{3}\right)(\mathrm{py})\right]$ increased the number of revertant colonies in both TA98 and 100 cells both with and without S9. By contrast, trans- $\left[\mathrm{PtCl}_{2}\left(\mathrm{NH}_{3}\right)\right.$ (py)] was only found to be mutagenic in TA100 cells, and in the presence of the S9 fraction. Therefore, trans-[Pt( $\left.\left.\mathrm{VPA}_{-1 \mathrm{H}}\right)_{2}\left(\mathrm{NH}_{3}\right)(\mathrm{py})\right]$ and trans- $\left[\mathrm{PtCl}_{2}\left(\mathrm{NH}_{3}\right)(\mathrm{py})\right]$ may be considered possible mutagens, a trend similar to that observed for cisplatin $[40,41]$.

\subsection{In vitro cytotoxicity}

The in vitro anti-cancer chemotherapeutic potential of a series of TPA dichlorido compounds and their corresponding TPA valproato analogues were determined using two human-derived ovarian cancer cell lines; parental cell line A2780 and cisplatin resistant variant A2780 cisR. Dose-response curves were plotted (data not shown) and used to calculate $\mathrm{IC}_{50}$ values (Table 4 ). Sodium valproate and transplatin were shown to be inactive in both cell lines. Additionally, the TPA compounds; trans-[ $\left[\mathrm{PtCl}_{2}(\mathrm{py})_{2}\right]$ and trans- $\left[\mathrm{PtCl}_{2}\left(\mathrm{NH}_{3}\right)(\mathrm{py})\right]$ exhibited little or no cytotoxicity at the maximum concentration used $(100 \mu \mathrm{M})$. Previously it has been shown that when the $\mathrm{NH}_{3}$ group of transplatin is substituted with $\mathrm{N}$-donor heterocycle ligands, such as pyridine, a cytotoxicity profile equivalent to that of cisplatin was observed [6]. In our study, we demonstrated that replacement of the dichlorido ligands in trans- $\left[\mathrm{PtCl}_{2}(\mathrm{py})_{2}\right]$ and trans- $\left[\mathrm{PtCl}_{2}\left(\mathrm{NH}_{3}\right)(\mathrm{py})\right]$ by valproato ligands $\left(\mathrm{VPA}_{-1 \mathrm{H}}\right)$ to yield trans-[Pt(VPA $\left.\left.-1 \mathrm{H}\right)_{2}(\mathrm{py})_{2}\right]$ and trans-[Pt $\left.\left(\mathrm{VPA}_{-1 \mathrm{H}}\right)_{2}\left(\mathrm{NH}_{3}\right)(\mathrm{py})\right]$ respectively, significantly enhanced cytotoxicity against A2780 and A2780 cisR cells. We also established that cytotoxicity was marginally enhanced in the cisplatin-resistant phenotype (A2780 cisR) over the parental phenotype (A2780) when cells were treated with both valproic acid complexes, trans-[Pt $\left.\left(\mathrm{VPA}_{-1 \mathrm{H}}\right)_{2}(\mathrm{py})_{2}\right]$ and trans-[Pt( $\left.\left.\mathrm{VPA}-1 \mathrm{H}\right)_{2}\left(\mathrm{NH}_{3}\right)(\mathrm{py})\right]$. Interestingly, Lin et. al. described how valproic acid was capable of re-sensitising cisplatin-resistant ovarian cancer cells in vitro [24] and Farrell and coworkers demonstrated that TPA compounds of the $\mathrm{N}_{2} \mathrm{O}_{2}$ donor set displayed greater accumulation in cisplatin-resistant tumour cells [13]. Cisplatin (e.g. IC $_{50}$ value of $2.9 \mu \mathrm{M}$ against A2780) and Farrell and co-worker's TPA carboxylato complexes, in contrast, are significantly more cytotoxic (e.g. IC I $_{50}$ values of $<20 \mu \mathrm{M}$ against A2780) than trans$\left[\mathrm{Pt}\left(\mathrm{VPA}_{-1 \mathrm{H}}\right)_{2}(\mathrm{py})_{2}\right]$ and trans-[Pt $\left.\left(\mathrm{VPA}_{-1 \mathrm{H}}\right)_{2}\left(\mathrm{NH}_{3}\right)(\mathrm{py})\right][13]$. Farrell's complex, trans-[Pt $\left(\mathrm{O}_{2} \mathrm{CH}\right)_{2}\left(\mathrm{NH}_{3}\right)$ (4-pic)], (4-pic $=4$ picolinic acid), which displayed the fastest hydrolysis and was the most water soluble of the TPA complexes studied had an $\mathrm{IC}_{50}$ of $6 \mu \mathrm{M}$ against the A2780 cell line for example [13].

\section{Conclusion}

The first examples of Pt complexes of the well known anti-epilepsy drug and HDAC inhibitor, valproic acid, trans-[Pt(VPA $\left.\left.{ }_{-1 \mathrm{H}}\right)_{2}(\mathrm{py})_{2}\right]$ and trans-[Pt $\left.\left(\mathrm{VPA}_{-1 \mathrm{H}}\right)_{2}\left(\mathrm{NH}_{3}\right)(\mathrm{py})\right]$ are reported. Valproic acid type ligands can bind to $\mathrm{Pt}(\mathrm{II})$ centres via the carboxylato functionality and in a
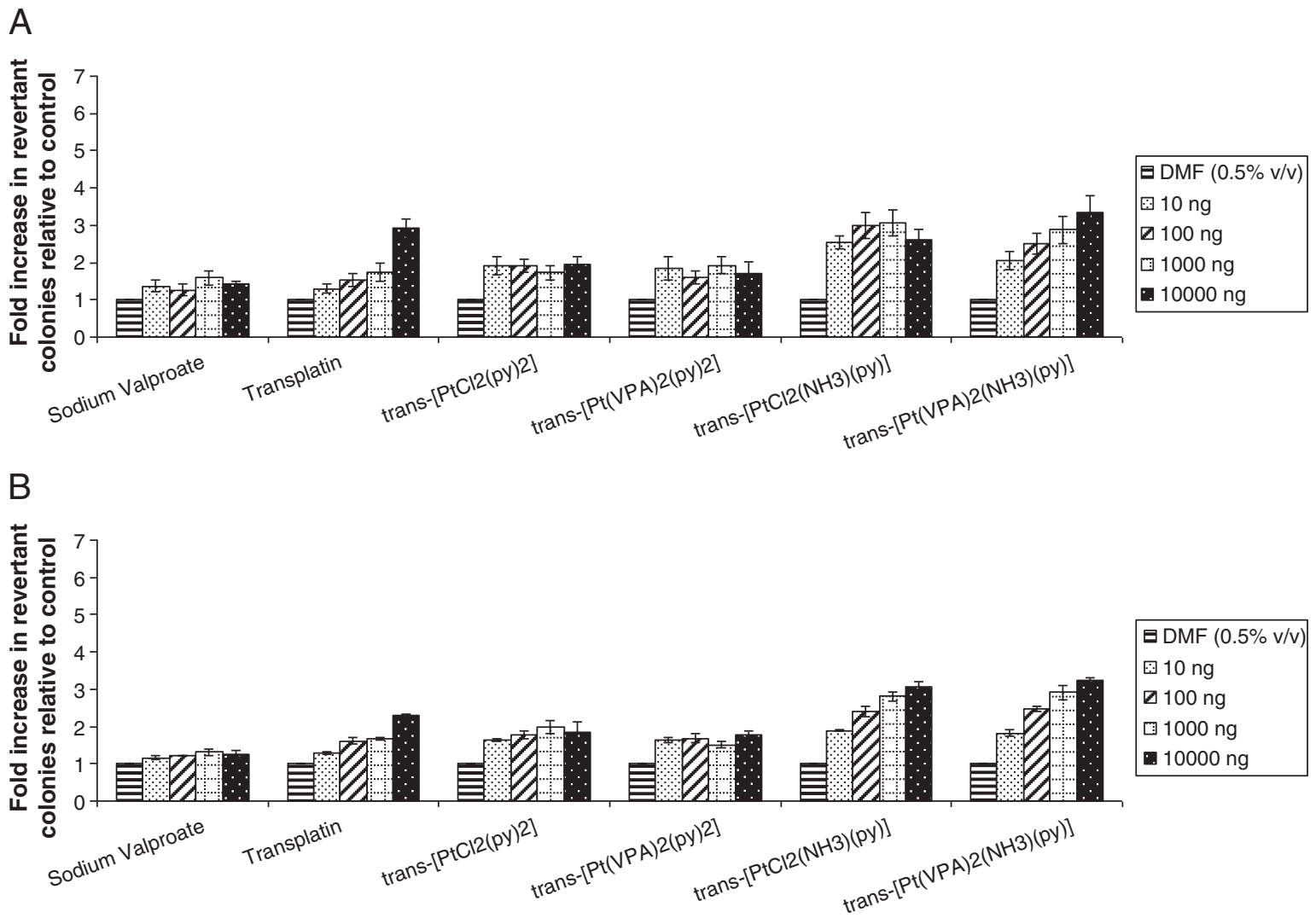

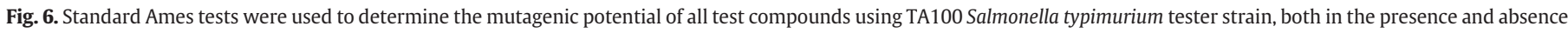

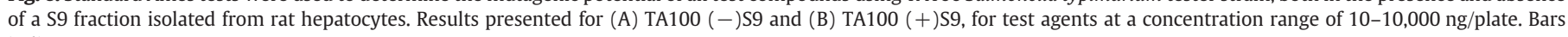
indicate \pm SEM, $\mathrm{n}=3$. 
Table 4

$\mathrm{IC}_{50}$ values $(\mu \mathrm{M})$ (mean \pm S.E.M.; $\mathrm{n}=3$ ) for test agents was determined using A2780 and A2780 cisR following $72 \mathrm{~h}$ of incubation. A graph of viability vs drug concentration was used to calculate all resultant $\mathrm{IC}_{50}$ values.

\begin{tabular}{|c|c|c|}
\hline \multicolumn{3}{|c|}{ Cytotoxicity mean $\mathrm{IC}_{50}(\mu \mathrm{M}) \pm$ S.E.M. } \\
\hline Test agent & A 2780 & A2780cisR \\
\hline Cisplatin & $2.9 \pm 0.1$ & $28.5 \pm 1.5$ \\
\hline Transplatin & $>100$ & $>100$ \\
\hline Sodium Valproate & $>100$ & $>100$ \\
\hline trans- $\left[\mathrm{PtCl}_{2}(\mathrm{py})_{2}\right]$ & $>100$ & $>100$ \\
\hline trans-[Pt(VPA $\left.-1 \mathrm{H})_{2}(\mathrm{py})_{2}\right]$. & $>100$ & $95.1 \pm 7.30$ \\
\hline trans- $\left[\mathrm{PtCl}_{2}\left(\mathrm{NH}_{3}\right)(\mathrm{py})\right]$ & $>100$ & $>100$ \\
\hline trans-[Pt $\left.\left(\mathrm{VPA}_{-1 \mathrm{H}}\right)_{2}\left(\mathrm{NH}_{3}\right)(\mathrm{py})\right]$ & $86.5 \pm 1.20$ & $76.3 \pm 4.20$ \\
\hline
\end{tabular}

monodentate manner. The X-ray crystal structure of the novel complex trans-[Pt $\left.\left(\mathrm{VPA}_{-1 \mathrm{H}}\right)_{2}\left(\mathrm{NH}_{3}\right)(\mathrm{py})\right]$ is also described. Replacement of the dichlorido ligands in TPA complexes significantly enhanced cytotoxicity against A2780 (parental) and A2780 cisR (cisplatin resistant) ovarian cancer cells. It is envisaged that development of TPA carboxylato complexes, where the carboxylic acid ligand is a more potent HDACI than valproic acid and one which would contribute positively to the hydrolysis and solubility profile of corresponding Pt complexes, may serve to enhance the cytotoxic potential of TPA complexes.

$\begin{array}{ll}\text { Abbreviations } \\ \text { ANOVA } & \text { analysis of variance } \\ \text { DMF } & \text { dimethylformamide } \\ \text { EBSS } & \text { Earle's balanced salt solution } \\ \text { FBS } & \text { foetal bovine serum } \\ \text { HAT } & \text { histone acetyltransferase } \\ \text { HDAC } & \text { histone deacetylase } \\ \text { HDACI } & \text { histone deacetylase inhibitor } \\ \text { MTT } & \text { 3-(4,5-dimethylthiazol-2-yl)-2,5-diphenyl tetrazolium } \\ & \text { bromide } \\ \text { NQNO } & \text { 4-nitroquinoline- } N \text {-oxide } \\ \text { ipa } & \text { isopropylamine } \\ \text { ORTEP } & \text { Oak Ridge Thermal Ellipsoid Plot } \\ \text { PBS } & \text { phosphate-buffered saline } \\ \text { 4-pic } & \text { 4 picolinic acid } \\ \text { py } & \text { pyridine } \\ \text { SAHA } & \text { suberoylanilide hydroxamic acid } \\ \text { TPA } & \text { trans-platinum planar amine } \\ \text { tz } & \text { thiazole } \\ \text { VPA } & \text { valproic acid, 2-propylpentanoic acid }\end{array}$

\section{Acknowledgements}

This material is based upon works supported by the Science Foundation Ireland under Grants No. [07/RFP/CHEF570] and [08/RFP/ CHE1675] and the Technological Sector Research Scheme, Strand III (2006), under the European Social Fund. We also gratefully acknowledge the Programme for Research in Third Level Institutions (PRTLI), administered by the HEA for funding.

\section{Appendix A. Supplementary data}

Crystallographic data (excluding structure factors) reported in this paper have been deposited with the Cambridge Crystallographic Data
Centre, CCDC No. 798570 (Copies of this information may be obtained free of charge from The Director, CCDC, 12 Union Road, Cambridge CB2 1EZ, UK (fax: ++44-1223-336-033; e-mail: deposit@ccdc.cam.ac.uk or www: http://www.ccdc.cam.ac.uk/products/csd/request/). Supplementary data to this article can be found online at doi: $10.1016 / \mathrm{j}$. jinorgbio.2011.03.001.

\section{References}

[1] M. Galanski, M.A. Jakupec, B.K. Keppler, Curr. Med. Chem. 12 (2005) 2075-2094.

[2] N.J. Wheate, S. Walker, G.E. Craig, R. Oun, Dalton Trans. 39 (2010) 8113-8127.

[3] L. Kelland, Nat. Rev. 7 (2007) 573-584.

[4] Y. Jung, S.J. Lippard, Chem. Rev. 107 (2007) 1387-1407.

[5] N. Farrell, T.T.B. Ha, J.P. Souchard, F.L. Wimmer, S. Cros, N.P. Johnson, J. Med. Chem. 32 (1989) 2240-2241.

[6] N. Farrell, L.R. Kelland, J.D. Roberts, M. Van Beusichem, Cancer Res. 52 (1992) 5065-5072

[7] N. Farrell, L.F. Povirk, Y. Dange, G. DeMasters, M.S. Gupta, G. Kohlhagen, Q.A. Khan, Y. Pommier, D.A. Gewirtz, Biochem. Pharmacol. 68 (2004) 857-866.

[8] S.M. Aris, N.P. Farrell, Eur. J. Inorg. Chem. (2009) 1293-1302.

[9] M. Coluccia, G. Natile, Anticancer Agents Med. Chem. 7 (2007) 111-123.

[10] U. Kalinowska-Lis, J. Ochocki, K. Matlawska-Wasowska, Coord. Chem. Rev. 252 (2008) 1328-1345.

[11] E.S.F. Ma, W.D. Bates, A. Edmunds, L.R. Kelland, T. Fojo, N. Farrell, J. Med. Chem. 48 (2005) 5651-5654.

[12] A.G. Quiroga, J.M. Perez, C. Alonso, C. Navarro-Ranninger, N. Farrell, J. Med. Chem. 49 (2005) 224-231.

[13] G.H. Bulluss, K.M. Knott, E.S.F. Ma, S.M. Aris, E. Alvarado, N. Farrell, Inorg. Chem. 45 (2006) 5733-5735.

[14] S.M. Aris, D.A. Gewirtz, J.J. Ryan, K.M. Knott, N.P. Farrell, Biochem. Pharmacol. 73 (2007) 1749-1757.

[15] D. Griffith, M.P. Morgan, C.J. Marmion, Chem. Commun. (2009) 6735-6737.

[16] D. Griffith, J.P. Parker, C.J. Marmion, Anticancer Agents Med. Chem. 10 (2010) 354-370.

[17] O.A. Botrugno, F. Santoro, S. Minucci, Cancer Lett. 280 (2009) 134-144.

[18] J.E. Shabason, P.J. Tofilon, K. Camphausen, Oncology 24 (2010) 180-185.

[19] S. Cang, Y. Ma, D. Liu, J. Hematol. Oncol. 2 (2009) 22.

[20] P.A. Marks, Oncogene 26 (2007) 1351-1356.

[21] W.K. Kelly, P.A. Marks, Nat. Clin. Pract. Oncologist 2 (2005) 150-157.

[22] M. Duvic, J. Vu, Expert Opin. Investig. Drugs 16 (2007) 1111-1120.

[23] A. Papi, A.M. Ferreri, P. Rocchi, F. Guerra, M. Orlandi, Anticancer Res. 30 (2010) 535-540.

[24] J. Hrebackova, J. Hrabeta, T. Eckschlager, Curr. Drug Targ. 11 (2010) 361-379.

[25] R.B. Erlich, D. Rickwood, W.B. Coman, N.A. Saunders, A. Guminski, Cancer Chemother. Pharmacol. 63 (2009) 381-389.

[26] C.-T. Lin, H.-C. Lai, H.-Y. Lee, W.-H. Lin, C.-C. Chang, T.-Y. Chu, Y.-W. Lin, K.-D. Lee, M.-H. Yu, Cancer Sci. 99 (2008) 1218-1226.

[27] D. Griffith, K. Lyssenko, P. Jensen, P.E. Kruger, C.J. Marmion, Dalton Trans. (2005) 956-961.

[28] D.M. Griffith, A. Haughey, S. Chahal, H. Müller-Bunz, C.J. Marmion, Inorg. Chim. Acta 363 (2010) 2333-2337.

[29] D. Griffith, A. Bergamo, S. Pin, M. Vadori, H. Mueller-Bunz, G. Sava, C.J. Marmion, Polyhedron 26 (2007) 4697-4706.

[30] D. Griffith, A. Chopra, H. Mueller-Bunz, C.J. Marmion, Dalton Trans. (2008) 6933-6939.

[31] D. Griffith, M. Devocelle, C.J. Marmion, in: A. Hughes (Ed.), Amino Acids, Peptides and Proteins in Organic Chemistry, Wiley-VCH, Weinheim, 2009.

[32] R.W. Hay, S. Miller, Polyhedron 17 (1998) 2337-2343.

[33] M. Pavelka, M.F. Lucas, N. Russo, Chem. Eur. J. 13 (2007) 10108-10116.

[34] G.B. Kaufman, D.O. Cowan, Inorg. Synth. 7 (1963) 239-245.

[35] Bruker AXS Inc., APEX2 and SAINT, Madison, Wisconsin, USA, 2005.

[36] G.M. Sheldrick, Acta Cryst. A64 (2008) 112-122.

[37] D.A. Maron, B.N. Ames, Mutat. Res. 113 (1983) 173-215.

[38] T. Mosmann, J. Immunol. Meth. 65 (1983) 55-63.

[39] K. Nakamoto, Infrared and Raman Spectra of Inorganic and Coordination Compounds Part B, John Wiley and Sons, New Jersey, 2009.

[40] H.J. Cross, M. Tilby, J.K. Chipman, D.R. Ferry, A. Gesher, Int. J. Cancer 3 (1996) 404-408.

[41] M.A. Hannan, A.A. Al-Dakan, S.S. Hussain, M.H. Amer, Toxicology 55 (1989) 183-191. 